\title{
Calcified pseudoneoplasm of the neuraxis
}

Figure $1 \quad$ CT and MRI of brain

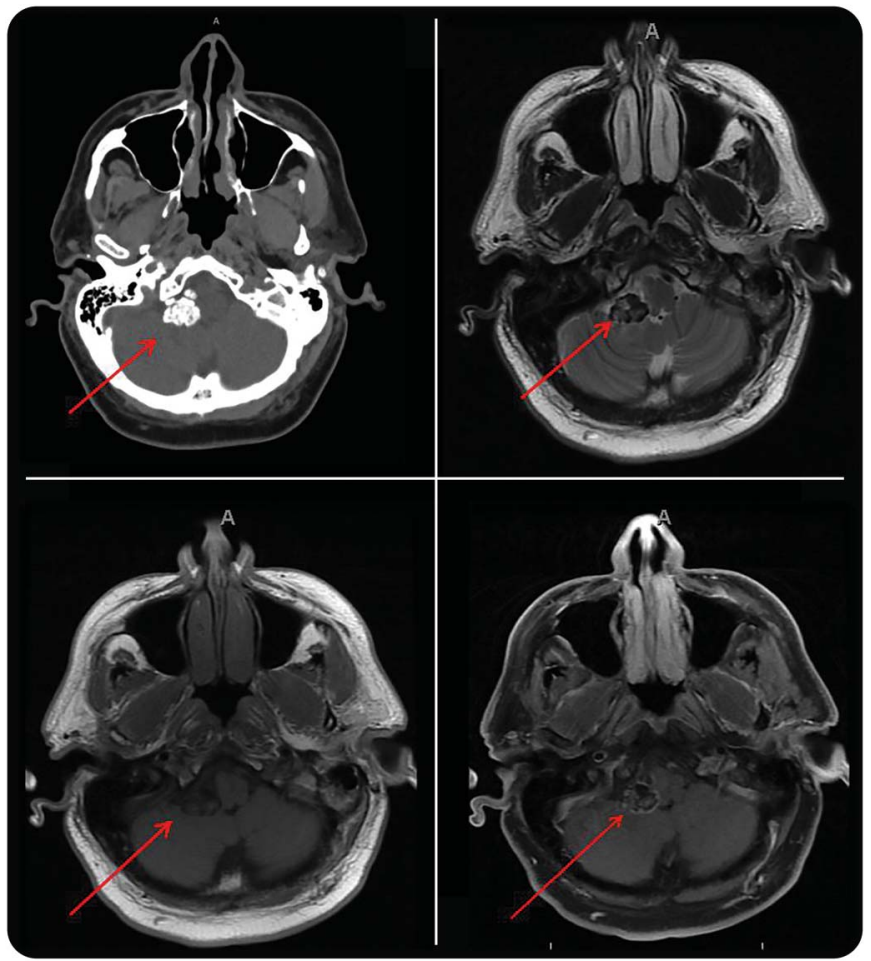

CT of the head shows a calcified mass in the right cerebellomedullary angle cistern. MRI demonstrates mild adjacent parenchymal edema and serpiginous contrast enhancement.

A patient presented with severe suboccipital headaches. Noncontrast CT was obtained and a densely calcified mass was found at the right cerebellomedullary angle cistern (figure 1). This lesion was followed clinically and with serial imaging. Follow-up MRI of the brain performed 8 months later demonstrated slightly increased mass effect and edema on the adjacent medulla and gross total surgical resection was performed. Final pathologic diagnosis was calcifying pseudoneoplasm of the neuraxis (CAPNON) (figure 2).

CAPNON are rare non-neoplastic lesions that typically arise in the extra-axial space in the brain and spine. The underlying cause of CAPNON is unclear, though it may represent reactive response to trauma, infection, or inflammation. ${ }^{1}$ Complete surgical resection seems to be curative.

Albert Lu, MD, Anoop Nundkumar, MD, Claudia M. Greco, MD, Peter Shen, MD

From the University of California Davis Medical Center, Sacramento.

Author contributions: Dr. Lu: concept and design, analysis and interpretation of data, drafting of manuscript. Dr. Nundkumar: concept and design, analysis and interpretation of data. Dr. Greco: analysis and interpretation of data, critical review of manuscript. Dr. Shen: concept and design, analysis and interpretation of data, critical review of manuscript.

Study funding: No targeted funding reported.

Disclosure: The authors report no disclosures relevant to the manuscript. Go to Neurology.org for full disclosures.

Correspondence to Dr. Lu: albert.lu@ucdmc.ucdavis.edu 


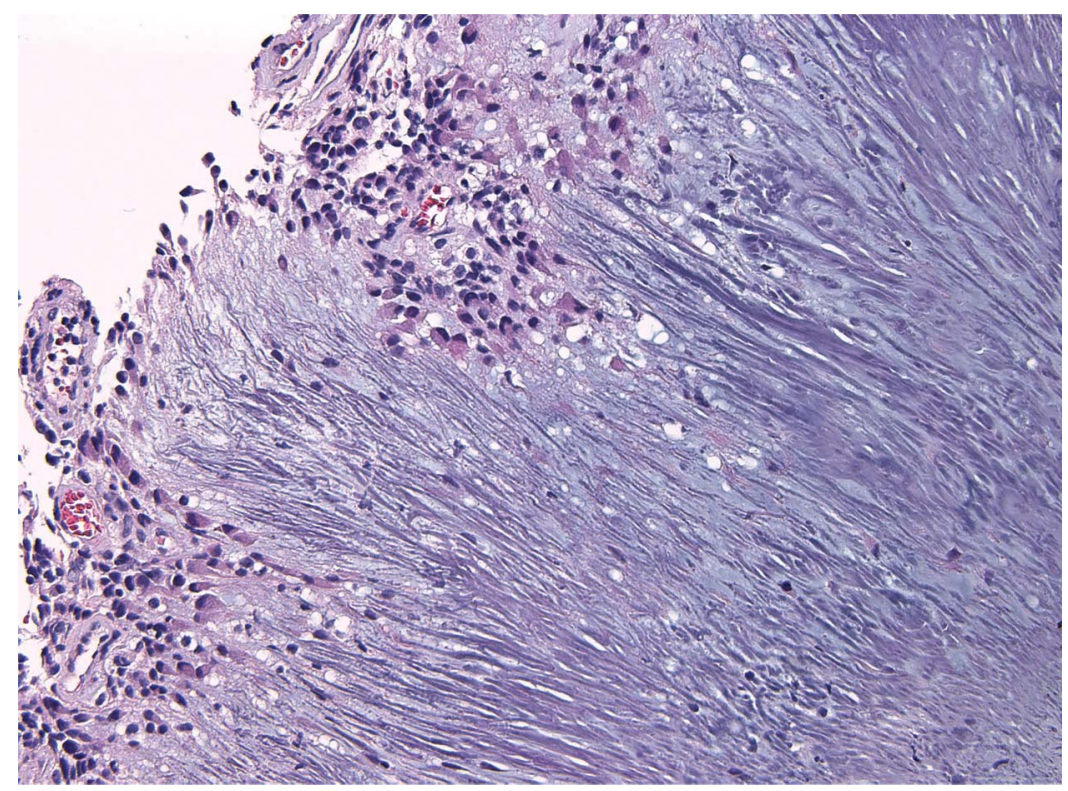

Characteristic histology includes overall paucicelluar composition with a fibrillar arrangement of acellular basophilic material. At its edges are clusters of reactive cells that include lymphocytes, plasma cells, and epithelioid macrophages.

1. Aiken AH, Akgun H, Tihan T, et al. Calcifying pseudoneoplasms of the neuraxis: CT, MR imaging, and histologic features. Am J Neuroradiol 2009;30:1256-1260.

\section{"EXTRA! Read All About the AAN-On Your New AANnews App!"}

Convenient, enriched, connected: The free $A A N n e w s^{\circledR}$ app that brings your membership news to your Android or iOS mobile device. Read about Academy events, products, and services, and connect directly to useful videos, resources, and AAN.com. Share articles with colleagues by email, Facebook, or Twitter. Download it today from your iTunes or Android app store.

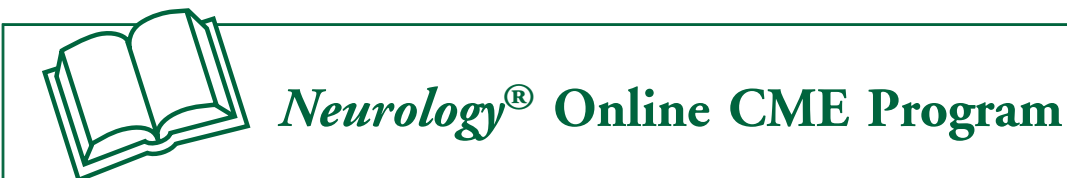

Earn CME while reading Neurology. This program is available only to online Neurology subscribers. Simply read the articles marked CME, go to Neurology.org, and click on CME. This will provide all of the information necessary to get started. The American Academy of Neurology (AAN) is accredited by the Accreditation Council for Continuing Medical Education (ACCME) to sponsor continuing medical education for physicians. Neurology is planned and produced in accordance with the ACCME Essentials. For more information, contact AAN Member Services at 800-879-1960. 


\title{
Neurology
}

\author{
Calcified pseudoneoplasm of the neuraxis \\ Albert Lu, Anoop Nundkumar, Claudia M. Greco, et al. \\ Neurology 2015;84;2289-2290 \\ DOI 10.1212/WNL.0000000000001645
}

This information is current as of June 1, 2015

\section{Updated Information \& Services}

References

Subspecialty Collections

Permissions \& Licensing

Reprints including high resolution figures, can be found at: http://n.neurology.org/content/84/22/2289. full

This article cites 1 articles, 1 of which you can access for free at: http://n.neurology.org/content/84/22/2289.full\#ref-list-1

This article, along with others on similar topics, appears in the following collection(s):

All Headache

http://n.neurology.org/cgi/collection/all_headache

CT

http://n.neurology.org/cgi/collection/ct

MRI

http://n.neurology.org/cgi/collection/mri

Primary brain tumor

http://n.neurology.org/cgi/collection/primary_brain_tumor

Information about reproducing this article in parts (figures,tables) or in its entirety can be found online at:

http://www.neurology.org/about/about_the_journal\#permissions

Information about ordering reprints can be found online:

http://n.neurology.org/subscribers/advertise

Neurology ${ }^{\circledR}$ is the official journal of the American Academy of Neurology. Published continuously since 1951, it is now a weekly with 48 issues per year. Copyright @ 2015 American Academy of Neurology. All rights reserved. Print ISSN: 0028-3878. Online ISSN: 1526-632X.

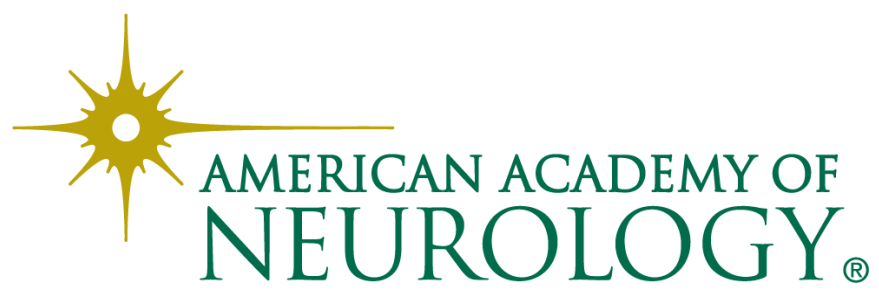

